\title{
INITIATION OF GRAPE (VITIS VINIFERA L.) ON DIFFERENT STERILIZATION TECHNIQUES
}

\author{
Ratu Mentari Dewi ${ }^{1)}$, Ramal Yusuf ${ }^{()}$, Sri Anjar Lasmini ${ }^{1)}$, Hawalina $^{\text {I) }}$ \\ ${ }^{1)}$ Study Program of Agrotechnology Faculty of Agriculture, Tadulako University, Palu \\ Email: ratumentaridw20@gmail.com, ryusufus@untad.ac.id, srianjar_lasmini@yahoo.com, hawalinak@yahoo.com
}

\begin{abstract}
The most crucial step during the development of tissue culture is the method of explant sterilization. Especially, explants is sourced directly from fields that were more susceptible to microbial contaminations. This study aimed to obtain sterilization technique from several sterilant for reduced contamination and support growth of shoots grape in vitro. This research was conducted at the Laboratory of Plant Biotechnology, Faculty of Agriculture, University of Tadulako, during January to April 2018. The study used a factorial completely randomized design, one factor was tested i.e S1 = Taft $8,3 \mathrm{~g} / \mathrm{L}(0,1 \%$ carbendazim $), \quad \mathrm{S} 2=$ taft $25 \mathrm{~g} / \mathrm{L}(0,3 \%$ carbendazim), S3 = taft 41,67 $\mathrm{g} / \mathrm{L}(0,5 \%$ carbendazim $), \mathrm{S} 4=$ Taft $8,3 \mathrm{~g} / \mathrm{L}(0,1 \%$ carbendazim $)+$ $\mathrm{HgCl}_{2} 0,1 \%$, S5 = Taft $25 \mathrm{gr} / \mathrm{L}(0,3 \%$ carbendazim $)+\mathrm{HgCl}_{2} 0,1 \%$ dan $\mathrm{S} 6=41,67 \mathrm{gr} / \mathrm{L} \quad(0,5 \%$ carbendazim) $+\mathrm{HgCl}_{2} 0,1 \%$. There were six treatment and each treatment was replicated three times to obtain 18 experimental units. Each experimental unit using two explant. Data were analyzed using analysis of variance and followed by Honestly Significant Difference test at level of $5 \%$ if the treatment effects were significant. The results showed sterilization technique using taft 41,67 gram / L containing $0.5 \%$ carbendazim for 30 minutes, followed by $70 \%$ alcohol for 30 seconds and $\mathrm{HgCl}_{2} 0,1 \%$ for 10 minutes gave free contamination for explant.whereas, Taft $8.3 \mathrm{~g} / \mathrm{L}$ (Carb $0.1 \%$ ) for $30 \mathrm{~min}$, followed by $70 \%$ alcohol for 30 seconds is a sterilization technique that does not inhibit explant growth as indicated from the most callus formation.
\end{abstract}

Key words: Carbendazim, Contamination, Grape, $\mathrm{HgCl}_{2}$, Sterilization, Shoots and Taft.

\section{INTRODUCTION}

Grape (Vitis vinifera L.) is one of the fruit crops that has high economic value and has been cultivated extensively in Palu City. Survey conducted on June to December 2017 showed the price of grapes around the city of Palu ranged between $\mathrm{Rp}$. 72,000 - Rp. 100,000 per kg. In addition to being consumed as fresh fruit, grapes can be processed into various types of products that can increase their economic value, such as grape juice, raisins, jams, wine vinegar, fruit salad mixture or flavor enhancers in yogurt, pudding and ice cream.

In terms of health benefits, Prihatman (2000) stated that phytochemical component in grape can prevent the formation of cancer cell and the content of secondary metabolites that act as antioxidant in counteracting free radical.
On the other hand, the graoe commodity seen from its production is still quite low. BPS (2015) reported that wine is a commodity with production less than $5 \%$ $(11,143$ tons) from total fruit production that contributes to national fruit production in Indonesia. Central Sulawesi BPS (2015) reports that grape production in Central Sulawesi was $642 \mathrm{kw}$.

Where as Central Sulawesi, especially in the city of Palu, has growing condition that is suitable for grape cultivation. BPS Palu (2014) reported that the height of the subdistrict in the Palu City area is mostly around $<500 \mathrm{~m}$ above sea level. Setiadi (2007) states that the optimum height of grape planting site ranges from 0 to $300 \mathrm{~m}$ above sea level, dry months / year at least 3 to 4 months. Nurcahyo (2005) states that grapes thrive with fruit in area with very high sunlight intensity for the process of flower and fruit growth . 
Table1. Sterilization Treatment Detail.

\begin{tabular}{cccc}
\hline Treatment & $\begin{array}{c}\text { \% Carbendazim } \\
\text { concentration of 30 minutes } \\
\text { taft (alcohol) }\end{array}$ & $\begin{array}{c}\text { Alcohol } \\
70 \% \\
\text { (soaked) }\end{array}$ & $\begin{array}{c}\text { Concentration \% HgCl } 10 \\
\text { minutes (soaked) }\end{array}$ \\
\hline S1 & 0,1 & 30 seconds & - \\
S2 & 0,3 & 30 seconds & - \\
S3 & 0,5 & 30 seconds & - \\
S4 & 0,1 & 30 seconds & 0,1 \\
S5 & 0,3 & 30 seconds & 0,1 \\
S6 & 0,5 & 30 seconds & 0,1 \\
\hline
\end{tabular}

Seeing the potential of high economic value, grow suitability and benefits so that this plant is important to be cultivated and be developed in Central Sulawesi, especially the area of Palu City.

In cultivating grape, a source of seed is needed, so that it can supply the large quantities. In condition where there is less availability, propagation through tissue culture can be chosen as alternative, with excess seed obtained free of pests, similar in nature to the parent and not dependent on the season in their production (Basri, 2004).

The initial stage in the multiplication of shoot culture is very important. Its success is supported by the provision of contamination of free explant. The sterilization method with the correct method, sterilizing material and the appropriate sterilization time to determine the success of the sterilization process.

Reeth and Shivamurthy (2005) reported that the most important stage during the growth of plant regeneration protocols to reduce contamination in woody species is explant sterilization methods.

Explant originating directly from the field without pre treatment is one of the causes of high contamination because they contain various sources of contaminants that attach to the surface of the explant. The use of mercury chloride $(\mathrm{HgCl} 2)$ has been carried out by several researchers, among others, Jan A. et al., (2013) for Strawberry (Fragaria $\mathrm{x}$ ananassa Duch.), Arifuzzaman (2016) for Grape (Vitis vinifera L.) and Anandan et al (2011) for Papaya (Carica papaya L.), it is used to overcome contaminants from the field.
The use of Dithane M.45 (mankozeb $80 \%$ ) fungicide as a method of grape sterilization is often used in the stage of tissue culture sterilization method. Another study with the use of Carbendazime (fungicide) combination of $0.1 \% \mathrm{HgCl} 2$ in grape shoot sterilization was carried out by Debbarma et al (2016), it was to obtain the success of sterile explants $97.50 \%$.

Taft $75 \mathrm{WP}$ is a fungicide that contains active ingredients $12 \%$ carbendazim and $63 \%$ mankozeb. The combination of the active ingredient content of the taft fungicide becomes a new thing to evaluate its effectiveness.

The importance of getting the right sterilization technique can be beneficial in the development of tissue culture multiplication especially for commercial.

Based on this description, it is necessary to conduct a sterilization technique research using Taft and $0.1 \%$ $\mathrm{HgCl} 2$ on the initiation of grape shoots.

\section{RESEARCH METHOD}

This research was conducted at Biotechnology Laboratory at Tadulako University from January to April 2018.

The tools used in this study were laminar air flow cabinet, refrigerator, electric oven, autoclave, tweezers, pipettes, culture bottle, stirring rod, bunsen burners, analytic scales, hot plates, beaker, measuring cups, culture shelves, plastic, filter paper, label paper, rubber bands, shakers, magnetic stirrers, handsprayers, documentation tools and writing instruments. 


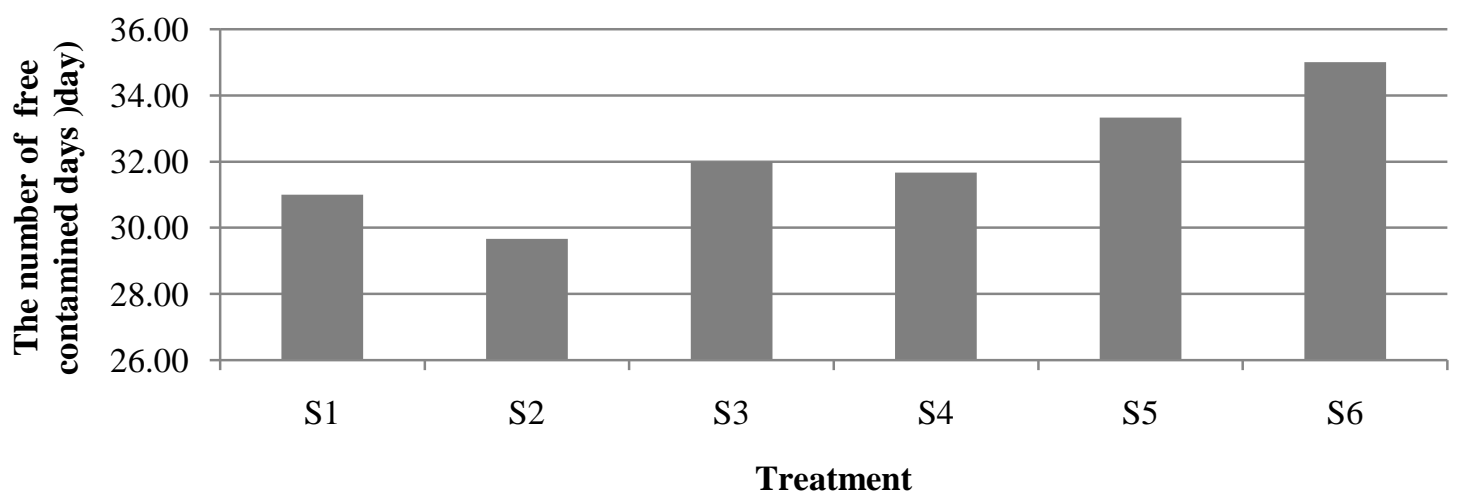

Figure 1. The Average Of Free Contamined Period For 35 Days After Planting.

The ingredients used are relatively young tertiary grape branches (still green) as sources of explants, sterile distilled water, $70 \%$ alcohol, detergents, spritus, $\mathrm{HgCl}$, tween 80, taft fungicides, sugar, gelatin, MS media composition, growth regulators $0.4 \mathrm{ppm}$ NAA and $2 \mathrm{ppm}$ BAP.

This study used CRD (Complete Random Design), namely sterilization treatment $(\mathrm{S})$ as follows: $\mathrm{S} 1=$ taft $8.3 \mathrm{gr} / \mathrm{L}$ (Carb 0.1\%), S2 = taft $25 \mathrm{~g} / \mathrm{L}($ Carb $0.3 \%)$, $\mathrm{S} 3=$ taft $41.67 \mathrm{~g} / \mathrm{L}($ Carb $0.5 \%), \mathrm{S} 4=\mathrm{taft}$ $8.3 \mathrm{~g} / \mathrm{L}(\mathrm{Carb} 0.1 \%)+\mathrm{HgCl} 20.1 \%, \mathrm{~S} 5=$ taft $25 \mathrm{~g} / \mathrm{L}($ Carb 0, 3\%) $+\mathrm{HgCl} 20.1 \%$, $\mathrm{S} 6=$ taft $41.67 \mathrm{~g} / \mathrm{L}(\mathrm{Carb} 0.5 \%)+\mathrm{HgCl} 2$ $0.1 \%$, the treatment was repeated 3 (three) times so that there were 18 (eighteen) unit experiments. Each experimental unit was planted with 2 (two) explants so that there were 36 (thirty six) explants.

Explant Sterilization. A branch of grape that has been cut between the book (one book) about $3 \mathrm{~cm}$ was cleaned in running water then shaken out in the solution (3 drops of detergent / $100 \mathrm{ml}$ and 2 drops of tween 80) for 10 minutes then rinsed with distilled water until clean. Furthermore, explant was sterilized according to the following treatment:

Contamination-free period. It was observed when there was first contamination by fungi or bacteria on explants in each bottle, it was calculated from the day after planting until 35 days after planting.

\section{Observation Variable.}

Level of Contamination Type. Observing and calculating contamined explants in each bottle by fungi or bacteria. It was observed since the day after planting for 35 days after planting.

\section{Freshness Level or Explant Browning.} observing and calculating explants that can survive. Browning is characterized by the tips of dark shoot and shoot can not grow while the freshness of explants is seen from the level of freshness (green shoots). Giving a score by comparing the level of freshness in all plant samples.

Callus formation. It was observed the callus formation rates and given a score score. Score giving was by comparing the level of freshness on explant.

Shoot formation. Observing and calculating shoot formation for 35 days after planting.

Data analysis. The data obtained were analyzed using Analysis of Variance. If the analysis showed a real and very real influence, then it is further tested by an Honestly Significant Difference (BNJ) level of $5 \%$ to find out the difference between the treatment being tried.

\section{RESULTS AND DISCUSSION}

Contamination Free Period, Level of Contamination Type and Freshness Level or Explant Browning. Diversity analysis 
showed that the sterilization treatment had no significant effect on the parameters, but the data were displayed in graphical form to see the difference in parameter response presented in Figure 1, 2 and 3.

Figure1. showed that the use of Taft $41.67 \mathrm{~g} / \mathrm{L}(0.5 \%$ carbendazim) followed by $\mathrm{HgCl} 20.1 \%$ gave the best results of all treatments. This can be seen in Figure1. On average, treatment S6 was free of contamination for 35 days after planting.

Figure 2. showed that the highest level of fungal contamination was Taft treatment $8.3 \mathrm{~g} / \mathrm{L}(0.1 \%$ carbohydrate $)$ and Taft $25 \mathrm{~g} / \mathrm{L}$ ( $0.3 \%$ carbendazim). Whereas, Taft $41.67 \mathrm{~g} / \mathrm{L}(0.5 \%$ carbendazim $)$ and Taft $8.3 \mathrm{~g} / \mathrm{L}(0.1 \%$ carbendzim $)+\mathrm{HgCl} 2$ $0.1 \%$ were the highest level of bacterial contamination. The level of bacterial and fungal contamination was found in Taft treatment $25 \mathrm{~g} / \mathrm{L}(0.3 \%$ carbendazim $)+$ $\mathrm{HgCl} 20.1 \%$ and on Taft $41.67 \mathrm{~g} / \mathrm{L}(0.5 \%$ carbendazim) $+\mathrm{HgCl} 20.1 \%$ not found fungal or bacterial contamination.

Figure 3 showed (S3) 4.167 gr/ 100 $\mathrm{ml}$ Taft (Carbendazim 0.5\%) giving a response to the low freshness or high browning level of explant compared to other treatments.

\section{Callus Formation and Shoot Formation.}

The diversity analysis showed a very significant effect on the parameter and carried out a further BNJ 5\% test to determine the differences in each treatment presented in Table 2 and 3.

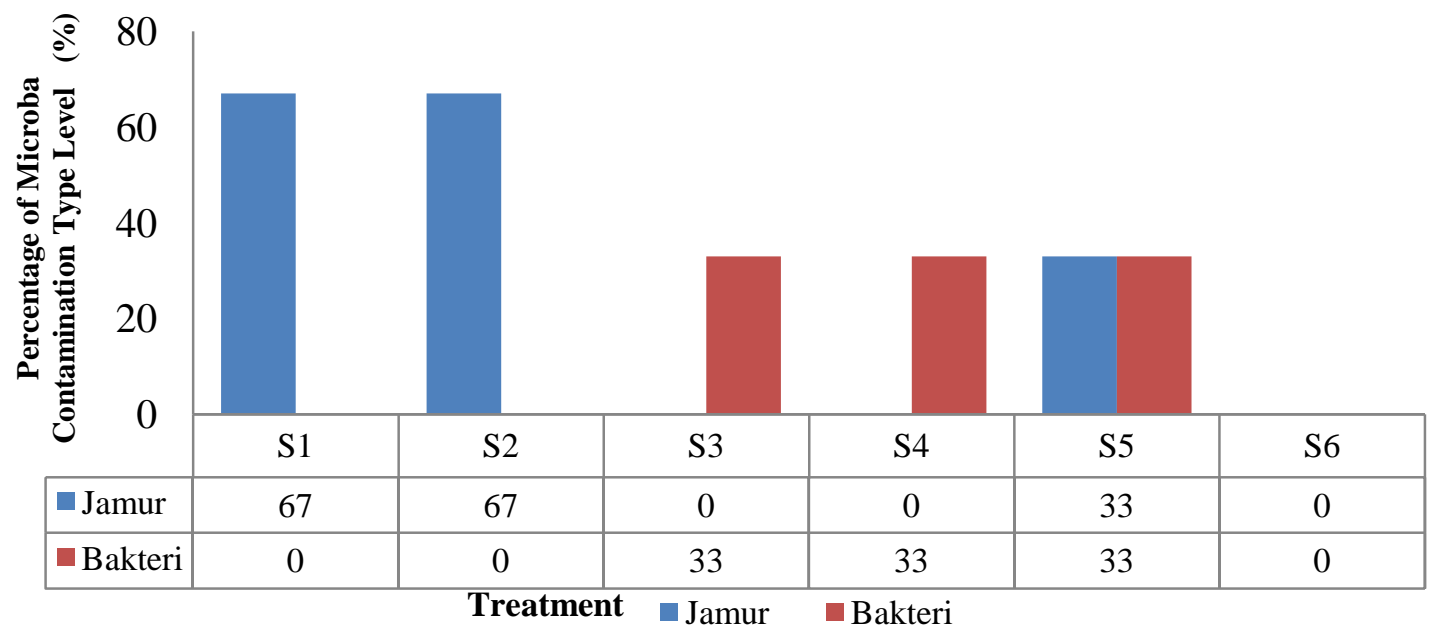

Figure 2. The average of contamination type level for 35 days after planting.

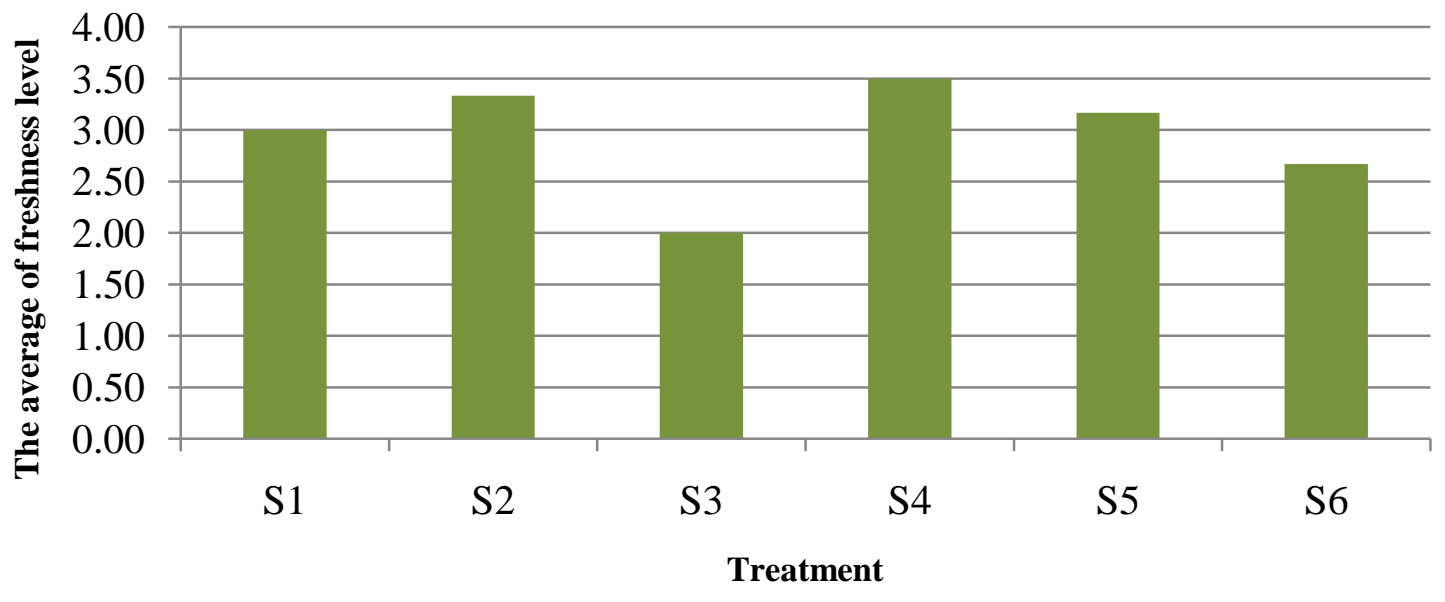

Figure 3. The average of explant freshness type level for 35 days after planting. 
Table 2. The average callus forming on the explant for 35 days after planting.

\begin{tabular}{lcc}
\hline \multicolumn{1}{c}{ Treatment } & Average & BNJ 5\% \\
\hline Taft 83 g/L (carb 0,1\%) & $2,50^{\mathrm{a}}$ & \\
Taft 25 g/L (carb 0,3\%) & $1,17^{\mathrm{b}}$ & \\
Taft 41,67 g/L (carb 0,5\%) & $2,00^{\mathrm{ab}}$ & 1,13 \\
Taft 83 g/L (carb 0,1\%) + $\mathrm{HgCl}_{2} 0,1 \%$ & $1,00^{\mathrm{b}}$ & \\
Taft 25 g/L (carb 0,3\%) + $\mathrm{HgCl}_{2} 0,1 \%$ & $1,33^{\mathrm{b}}$ & \\
Taft 41,67 g/L (carb 0,5\%) $+\mathrm{HgCl}_{2} 0,1 \%$ & $2,33^{\mathrm{ab}}$ & \\
\hline
\end{tabular}

Description : from the numbers followed by letter were not really different at BNJ test of $5 \%$ level.

Table 3. The average of shoot formation for each explant for 35 days after planting.

\begin{tabular}{lcc}
\hline \multicolumn{1}{c}{ Treatment } & Average & BNJ 5\% \\
\hline Taft 8,3 g/L (carb 0,1\%) & $1,07^{\mathrm{b}}$ & \\
Taft 25 g/L (carb 0,3\%) & $1,07^{\mathrm{b}}$ & \\
Taft 41,67 g/L (carb 0,5\%) & $0,80^{\mathrm{b}}$ & 0,33 \\
Taft 8,3 g/L (carb 0,1\%)+ $\mathrm{HgCl}_{2} 0,1 \%$ & $1,07^{\mathrm{b}}$ & \\
Taft 25 g/L (carb 0,3\%)+ $\mathrm{HgCl}_{2} 0,1 \%$ & $1,07^{\mathrm{b}}$ & \\
Taft 41,67 g/L (carb 0,5\%)+ $\mathrm{HgCl}_{2} 0,1 \%$ & $1,47^{\mathrm{a}}$ & \\
\hline
\end{tabular}

Description : from the numbers followed by letter were not really different at BNJ test of $5 \%$ level.

The 5\% BNJ Test resulted in Table 2 showed that the Taft $83 \mathrm{~g} / \mathrm{L}$ (Carb $0.1 \%$ ) treatment (S1) obtained the highest callus formation (2.50) and significantly different from (S2) $25 \mathrm{~g} / \mathrm{L}$ Taft (Carb $0.3 \%$ ), (S4) Taft $8.3 \mathrm{~g} / \mathrm{L}$ (Carb 0.1\%) + $\mathrm{HgCl} 20.1 \%$ and (S5) Taft $25 \mathrm{~g} / \mathrm{L}$ (Carb 0.3\%) + $\mathrm{HgCl} 2$ $0.1 \%$. But not significantly different from (S4) Taft $8.3 \mathrm{~g} / \mathrm{L}$ (Carb $0.1 \%)+\mathrm{HgCl} 2$ $0.1 \%$ and (S6) Taft $41.67 \mathrm{~g} / \mathrm{L}$ (Carb 0.5\%) $+\mathrm{HgCl} 20,1 \%$. The lowest average callus formation was obtained in S4 treatment (1.00)

BNJ test results of $5 \%$ in Table 3 showed (S6) Taft $41.67 \mathrm{~g} / \mathrm{L}$ (Carb $0.5 \%)+$ $\mathrm{HgCl} 20.1 \%$ giving the highest shoot formation (1.47 shoots) and significantly different from other treatments. Whereas the treatment (S3) Taft $41.67 \mathrm{~g} / \mathrm{L}(0.5 \%$ carb) results in the lowest shoot formation (0.80 shoot).

\section{Discussion}

The right concentration of sterile material can reduce the occurrence of contamination and reduce damage of explant so that it can support the success of tissue culture, especially in grape (Vitis viifera L.). According to Wulandari and Nasution (2014) contamination is a major problem in the first initiation stage in in vitro culture. The type of contamination that often occurs is bacteria and fungi.

Observation results for 35 days after planting on the initiation of grape shoot showed that the dominant contamination was caused by fungi compared to bacteria. Physical characteristics can be seen in explant and culture media. When exposed to fungal contamination, explant will appear fungal hyphae on the affected part and usually there were lines such as fine threads that was white to gray while bacterial contamination tends to look wet and cause mucus.

Carbendazim $0.5 \%$ (Taft) with a combination of $\mathrm{HgCl} 20.1 \%$ gave the best results for free period of contamination up to age 35 HST compared to other treatments. This was in line with (2016) where the use of carbendazim $0.5 \%$ with a combination of $0.1 \% \mathrm{HgCl} 2$ in grape shoot 
tissue culture gave the lowest contamination percentage results. However, it cannot be said that other treatments do not have a good effect on elimination and suppression of contamination by microbes. According to Basri (2004) identification of fungal or bacterial contamination can usually start from 2 days to 2 weeks after planting.

From Figure 1. It can be seen the treatment response Taft $8.3 \mathrm{~g} / \mathrm{L}(0.1 \%$ Carb), $25 \mathrm{~g} / \mathrm{L}$ Taft (0.3\% Carb), $41.67 \mathrm{~g} /$ L Taft (0.5\% Carb), Taft 8, $3 \mathrm{~g} / \mathrm{L}(0.1 \%$ Carb) $+0.1 \% \mathrm{HgCl} 2$ and $25 \mathrm{~g} / \mathrm{L}$ Taft $(0.3 \% \mathrm{Carb})+0.1 \% \mathrm{HgCl} 2$ affected the contamination of free period up to 28 days. Zulkarnain (2009) stated that contamination can occur due to the presence of microorganisme that survive in plant tissue until condition be favorable for their growth.

The use of disinfectant chemical can affect toxic to microorganism but not to the explant (Krikorian, 1962) but the use of concentration can have an impact on the occurrence of browning processes that affect explant survival and explant development.

Addition of $41.67 \mathrm{~g} / \mathrm{L}$ Taft affects the necrotic occurrence in plant tissue characterized by browning on explant (tissue death) due to high Taft concentration, in addition to the content of phenolic compounds found in the shoot.

Sterilization material that was too thick (high) and too soaking time that was too long can eliminate the source of contaminant but can also inhibit the growth of explant and even kill plant tissue (Rismayani and Hamzah, 2010).

Bhojwani and Razdan (1983) stated that Sterilization materials is toxic to plant tissue. Therefore, the level of concentration and length of treatment must be taken into account to reduce the risk of tissue death.

Apart from the use of concentration of sterile ingredients. George and Sherrington (1984) stated that the cause of browning caused by tropical plant has high phenol compound and will be oxidized when cells are injured. Browning that occurs will cause brown or blackish tissue and inhibit growth or failure to grow (dead explants).

Browning in tissue culture is caused by increased production of phenolic compound followed by oxidation by oxidase enzyme activity and polymerization. One of the enzymes in phenylpropanoid which affects the occurrence of browning is Fenilanin ammonia liase (PAL). The cause of browning is due to the removal of the cutting on the tissue that can stimulate stress and cause an increase in the activity of PAL enzyme and followed by the production of phenylpropanoid that cause browning (Tabiyeh et al, 2006).

However, shoot at the treatment of $41.67 \mathrm{~g} / \mathrm{L}+0.1 \% \mathrm{HgCl} 2$ had the ability to grow and to survive compared to the 41.67 g / L treatment shown in Table 4. Shoot formation and Table 5. callus formation.

Callus formation of all explants dominated in this study. Besides media, internal factors can affect the formation of callus caused by the presence of endogenous hormones that play a role in cell division ability (callus formation).

This had happened to Cerianingsih's (2015) study of in vitro culture of aksilar grape shoot and reported that the concentration of endogenous hormones in plants affects callus formation even though the concentration and type of growth regulating substances given are the same. Zulkarnain (2009) states that it is not easy to make generalizations about tissue responses to plant hormones.

\section{CONCLUSION AND SUGGESTION}

\section{Conclusion}

The sterilization technique using taft $41.67 \mathrm{~g} / \mathrm{L}(0.5 \% \mathrm{Carb})$ for 30 minutes, followed by $70 \%$ alcohol for 30 seconds and $0.1 \% \mathrm{HgCl} 2$ for 10 minutes gave the results of contamination-free explants for 35 HST. Meanwhile, giving Taft $8.3 \mathrm{~g} / \mathrm{L}$ (Carb $0.1 \%$ ) for 30 minutes, followed by alcohol $70 \%$ for 30 seconds showed the most callus formation. 


\section{Suggestion}

Explanation of browning treatment on grape shoot due to sterilization with taft use.

\section{REFERENCES}

Anandan, R., Thirugnanakumar, S., Sudhakar, D and P. Balasubramanian, 2011. In vitro organogenesis and plantlet regeneration of (Carica papaya L.). Journal of Agricultural Technology 7(5): 1339-1348.

Arifuzzaman M., Sultana S., Hossain MS. Saifullah, Naser R., Alim S and Hasan, 2016. Paraphernalia of Growth Regulators During In Vitro micro-Propagation of Grapevine (Vitis vinifera L.) from Shoot Tips and Nodal Segments. Sch J Agric Vet Sci. Vol 3(4): 326-331.

Basri, Z., 2004. Kultur Jaringan Tanaman. Universitas Tadulako Press, Palu.

Badan Pusat Statistik. 2015. Statistik Produksi Hortikultura Tahun 2014. Direktorat Jendral Hortikultura, Kementrian Pertanian.

Badan Pusat Statistik. 2015. Sulawesi Tengah dalam Angka. BPS Provinsi Sulawesi Tengah

Cerianingsih, M.W., I. A. Astarini dan G.M. Nurjaya, 2015. Pengaruh Kombinasi Zat Pengatur Tumbuh IBA dan BAP pada Kultur in Vitro Tunas Aksiler Anggur (Vitis vinifera L.) Varietas Prabu Bestari dan Jestro AG 86. Jurnal Metamorfosa II (1):1-8.

Debbarma, R., Suresh, J., Nagar D and Kambale, R., 2016. Efficient Sterilization Protocol for Micro Propagation of Grapevine cvs. Red Globe and Crimson Seedless. The Ecoscan Vol $9: 621-625$.

George, E.F and P.D Sherington. 1984. Plant Propagation by Tissue Culture : Hand Book and Directory of Comercial Laboratorius. Exegenetics Ltd., England.

Jan A., Bhat K.M., Bhat, Mir M. A., Bhat M.A., Antiyaz., Wani and Rather, 2013. Surface Sterilization Method for Reducing Microbial Contamination of Field Grown Strawberry Explants Intended for In Vitro Culture. Academic Journals. Vol 12 (39): 5749-5753.

Krikorian, A.D. 1962. Cloning higher Palants from Aseptically Cultured tissues and Cells. Bio. $\operatorname{Rev} 57: 157-181$.

Nurcahyo, Eko. M., 2005, Anggur dalam Pot, Jakarta : Penebar Swadaya

Prihatman, K., 2000. Shootidaya Pertanian Anggur. Sistem Informasi Pembangunan di Pedesaan, BAPPENAS.

Reeth PM and Shivamurthy GR (2005). Method to overcome the exudation of phenols in Nyctanthes arbor-tristis L. during in vitro mass propagation. Phytomorphology 55(3-4): 283-288.

Rismayani dan F. Hamzah. 2010. Pengaruh Pemberian Chorox (NaOCl) Pada Sterilisasi Permukaan Untuk Perkembangan Bibit Aglaonema (Donna carmen) SecaraInVitro.Prosiding Seminar Ilmiah dan Pertemuan Tahunan PEI dan PFI XX Komisariat Daerah Sulawesi Selatan, 27 Mei 2010. 
Tabiyeh, D.T., F. Bernard, and H. Shacker. 2006. Investigation of glutathione, salicylic acid and GA3 effects on browning in Pistacia vera shoot tips culture. ISHS Acta Hort. 726.

Wulandari Arum S., dan Nasution Sabar S., 2014. Pengaruh Bahan Sterilan terhadap Keberhasilan Inisiasi EksplanPaulownia (Paulownia elongata SY Hu) secara In Vitro.Jurnal Silvikultur Tropika Vol 5 (1) : 1-6

Zulkarnain, 2014. Kultur Jaringan Tanaman Solusi Perbanyakan TanamanShootidaya. Bumi Aksara, Jakarta. 